\title{
The Impact of Muslim Religiosity on Environmentally Friendly Behavior: The mediating role of Eco- Literacy and Environmental Concern
}

\author{
Nurhaida, Dida ${ }^{1}$; Kusuma Wijaya, $\mathrm{Aji}^{2}$; Fazriah, Siti $^{3}$ \\ \{dida.nurhaida@trisakti.ac.id ${ }^{1}$, aji.kusuma@trisakti.ac.id² \\ Faculty of Economics and Business, Trisakti University, Jakarta, Indonesia
}

\begin{abstract}
Environmental sustainability is a very important issue today because it is related to the continuity of human life on earth. Various studies have proven that the current ecological crisis has caused the existence of the environment to be significantly threatened. In the Islamic perspective, the ecological crisis is basically related to spiritual crisis. The objective of this study is to analyse the influence the level of religiosity to eco-literacy and environmental concern towards ecologically conscious behaviour among Moslem Society in Indonesia. This explationary research tries to explore the causal relationship between variables through hypothesis testing, by collecting data from 210 respondents through a questionnaire. Structural equation modelling (SEM) was used to test the influence of three levels of religiosities-Islam, Faith, Ihsan-to the mediating variable: eco-literacy and environmental concern, and then how does this mediating variable affect the ecologically conscious behaviour. The findings suggest that religiosity can play an important role in determining ecologically conscious behaviour among Muslim society in Indonesia.
\end{abstract}

Keywords: Green Behaviour; Green Consumption; Structural Equation Modelling; Moslem Religiosity

\section{Introduction}

Maintaining the preservation of nature is a very important action for the sustainability of human life. Islam teaches that people are always grateful for the grace of nature and its resources given by Allah to the human life. Expressions of environmental gratitude become one of the moral foundations, because it can prevent humans from greed and exploitative behavior. Maintaining the balance of nature is a core principle of the Islamic worldview, by preserving and sustaining the welfare of nature to bring peace to its inhabitants [1], [2]. For this reason, preserving nature is a very important action for the sustainability of human life. Thus, environmentally friendly behavior is needed in various forms as a manifestation of human actions that aim to minimize negative impacts on the environment.

The main problem in the environment is the imbalance that occurs in nature caused by human behavior. Humans always want to meet the needs of their lives, but often do not consider the harmony and balance of the environment. Human behavior that does not care about the 
environment cause environmental incompatibility and imbalance that results in damage, thus threatening nature conservation.

One of the factors that can encourage environmentally friendly behavior is religiosity. This is because religiosity can foster literacy and caring attitudes from the community towards environmental sustainability [3]. Comprehensive Muslim religiosity can be seen from behavior or activities (Islam), belief in God (Faith), and the spirit of self-actualization to do good and benevolence (Ihsan) [4]. A number of studies on the relationship between religiosity and environmentally friendly behavior have been carried out, both in Indonesia and in other countries [5]-[11]. However, there is no research that uses the Muslim religiosity scale comprehensively to measure the influence of religiosity factors on environmentally friendly behavior of Muslims in Indonesia.

The purpose of this study is to describe the relationship between the variables of Islamic religiosity which includes Islam, Iman and Ihsan on the environmentally friendly behavior of Muslims mediated by the level of eco-literacy and environmental concern. This study will provide an effective way for Muslims to achieve competitive advantage in complex conditions, by manifesting religious behavior with better reliability and efficiency in achieving environmentally friendly behavior, so this study was conducted to answer this need.

\section{Literature Review}

\subsection{Moslem Religiosity}

Islam literally means submission to whatever has power over a person, and the word of Islam specifically refers to obedience to Allah SWT. In Islam, religion is a bond created between God as the highest reality and His creation, with humans as one of his creations [4]. It is the way of life (al-din) or path (tariqat) with God as the anchor that encompasses the entire work, belief, and existence of a Muslim. The concept of Al-din includes three essential constituents. The first is Islam, which includes one's religious obligations marked by worship. The second is Faith, which represents a cognitive system and belief in the understanding of God. The third is Ihsan, which represents the actualization of moral and spiritual excellence.

Based on the concept of religiosity, one can surrender to God in three levels. At the first level is the Islamic level, this is done through religious works or practices such as worship and rituals, such as performing prayers, pay zakat and sadaqoh, fasting, hajj, and other social obligations. The Faith level involves understanding and belief in God, the prophets, angels, scriptures, and his resurrection. The last level of religiosity is Ihsan, this level is closely related to a person's inner dimension, where a person performs supererogatory worship in his devotionto Allah SWT. This can be seen as a spiritual transformation from exoteric to esoteric with the aim of becoming insan kamil (perfect or universal human) or the actualization of virtue and goodness, in line with the role that God has set for humans as caliphs on earth.

With this background, it can be said that the definition of religiosity emphasizes physical actions or human activities (Islam), thoughts or belief in God (Iman), and the spirit or actualization of virtue and goodness (Ihsan). To become a religious individual, these three concepts must be owned or implemented continuously. Based on this framework, the construct of "religiosity" for the scale developed in this study is measured by items that assess various aspects of a person's in dimensions of Islam, Iman, andIhsan. Thus, the following hypotheses are considered:

$\mathrm{H}_{1}$ : The level of Islam has a positive and significant direct effect on religiosity. 
$\mathrm{H}_{2}$ : The level of Iman faith has a positive and significant direct effect on religiosity.

$\mathrm{H}_{3}$ : The level of Ihsan has a positive and significant direct effect on religiosity.

\subsection{Eco-Literacy}

Eco-Literacy or Environmental literacy shows an individual's ability to identify and understand symbols, concepts, and behaviors related to the environment and refers to knowledge that helps in developing an understanding among individuals that the resources provided by nature are limited and need to be protected in order for the planet to remain a sustainable place to live. safe for present and future generations [3]. Islam as a religion that kaffah discusses all aspects of life, which is not only related to the human relationship with Allah Subhanahu Wa Ta'ala, but also relates to the relationship between humans and other humans and even the relationship between humans and their environment. There are many verses both in the Qur'an and hadith that call on Muslims to protect the natural environment, including: QS 2:30, QS 7:56, QS 7:96 [12].

Islam also encourages its adherents to acquire knowledge. Knowledge is a prerequisite for the creation of a just world. For Muslim consumers, environmental literacy plays an important role in influencing purchasing decisions for environmentally friendly products. Thus, Muslim individuals tend to try harder to gain knowledge about existing environmental problems and their solutions [3], [8]. The literature review is expected to support the following hypothesis: $\mathrm{H}_{4}$ : The level of religiosity has a positive and significant direct effect on eco-literacy.

Religiosity is defined as the extent of knowledge, how strong the belief is, how orderly in carrying out worship and how deep is the appreciation of religion. For a Muslim, religiosity can be known from the breadth of knowledge, belief, implementation and appreciation of Islamic teachings. Religion is an important element in the conceptualization and operationalization of religiosity [7]. A person's religiosity is seen as playing an important role in preserving the environment. The literature review supports the following hypothesis:

$\mathrm{H}_{5}$ : The level of religiosity has a positive and significant direct effect on evironmental concern

$\mathrm{H}_{6}$ : The level of religiosity has a positive and significant direct effect on enironmental friendly behavior.

Individual knowledge about environmental issues can increase consumer attention to the environment and environmental care behavior, even consumers are willing to buy or pay more for environmentally friendly products [8], [13]. Therefore, humans are required to protect the environment. A study conducted by Fitri et al [10] proves that a person's environmental knowledge greatly influences a person's behavior in deciding to purchase environmentally friendly products. The literature review supports the following hypothesis:

$\mathrm{H}_{7}$ : Eco-Literacy has a positive and significant direct effect on environmentally friendly behavior

\subsection{Environmental Concern}

According to Gifford \& Sussman [14], an attitude of caring for the environment has the dimensions of environmental preservation and utilization. People's concern for the environment continues to change from time to time, and varies depending on age, gender, socioeconomic status, nation, urban-rural residence, religion, politics, personality values, experience, education, and environmental knowledge [14]. It is important to understand the attitude of caring for the environment to overcome many environmental problems that occur today, ranging from 
local issues such as air and water pollution to global issues such as climate change [15].

Concern for environmental sustainability is defined as the degree of individual awareness of environmental problems and their readiness to participate in mitigating these problems. Individuals are expected to have a high concern for the environment in order to change their consumption patterns for environmental sustainability [3]. There are ideas regarding the positive and negative relationship between religiosity and environmental concern. For example, JudeoChristians tend to be more environmentally oriented than non-believers [8]. In addition, a positive relationship between religiosity and concern for the environment was found in India by [3]. The attitude of caring for the environment is defined as the degree of public awareness of environmental problems and their readiness to participate in mitigating these problems. Attention to the environment has a direct influence on increasing consumption of environmentally friendly products [8]. Attention to the environment is directly proportional to consumer attitudes towards environmentally friendly products [16]. The literature review supports the following hypothesis:

$\mathrm{H}_{8}$ : Environmental concern has a positive and significant direct effect on environmental friendly behavior

\subsection{Environmental Friendly Behavior}

Environmentally friendly behavior is behavior carried out by the community based on general knowledge principles (or according to environmental knowledge) to protect the environment. Environmentally friendly behavior is a series of actions taken by people in society towards the environment and is manifested in various emotions, tendencies and special readiness to behave towards the environment [17].

Attitude toward green products (ATGP) is a person's tendency to act positively or negatively towards environmentally friendly products. Consumers who care about the environment tend to buy environmentally friendly products. ATGP has an important role in influencing individual buying interest in environmentally friendly products [8]. The following following hypotheses have been developed to test the mediating effect:

$\mathrm{H}_{9}$ : Environmental concern have a positive and significant direct effect on environmentally friendly behavior

$\mathrm{H}_{10}$ : Environmental concern mediates the relationship between religiosity environmentally friendly behavior

$\mathrm{H}_{11}$ : Environmental concern mediates the relationship between eco- literacy and environmentally friendly behavior

H12: Eco-Literacy and environmental concern mediates the relationship between religiosity and environmentally friendly behavior

Thus, this study will analyze the influence and significance of the level of Muslim religiosity on environmentally friendly behavior mediated by eco-literacy factors and environmental concern. All the hypotheses that have been described previously are arranged into a research model which is shown in the following figure. 


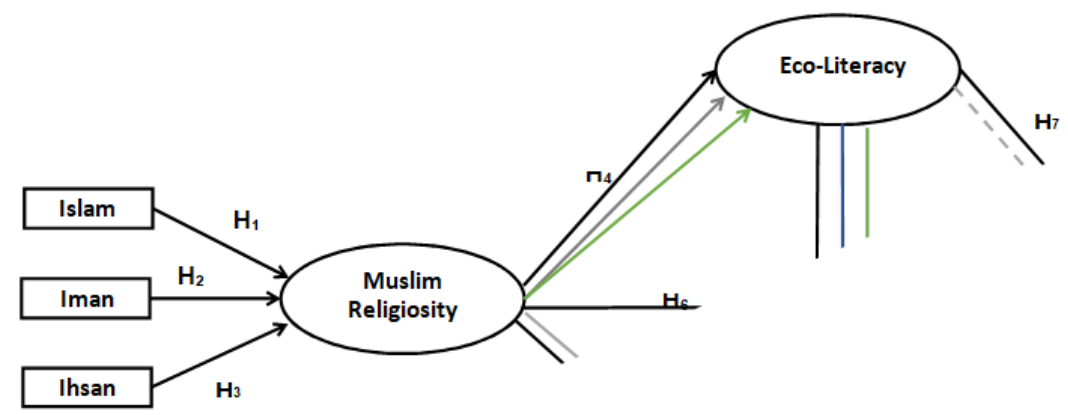

Fig. 1. Theoretical framework and hypothesis

\section{Methodology}

\subsection{Population, Sampling and Data Collection}

The population for this research is the Muslim community with various professions and educational background in the Jakarta, Bogor, Depok, Tangerang and Bekasi (JABODETABEK) areas, which is considered as a big city in Indonesia. Sampling data was collected through an online questionnaire in the form of a google form due to the covid 19 pandemic. Data collection started from January 1, 2021 to June 30, 2021. Non-probability sampling was used to gathered the datas, by distributing questionnaires through social media, awider population can be reached and the questionnaire forms are shared publicly.

The number of samples in this study was 210 people. The sampling consideration used in this study is the minimum sample size of 5 to 10 times all statement items in the research instrument used [18]. Referring to the theory, in this study, 29 number of statementitems were used, so the minimum sample size was 145 people, and the maximum sample size was 290 people. The criteria for respondents in this sample were taken based on the age, educational and professional backgrounds of the respondents.

\subsection{Measurement}

The research instruments used include the Religiosity questionnaire formed by Islam, Iman, and Ihsan, Eco-Literacy, Environmental Concern, and Environmentally Friendly Behavior which have high reliability and validity on each instrument. All items in the questionnaire were measured using a 5-point Likert scale, where 1 means "strongly disagree" and 5 means "strongly agree".

\subsection{Tools of Analysis}

The data was processed using PLS-SEM (Partial Least Square - Structural Equation Modeling) using WarpPLS Version 7.0 (2020). The test was carried out in two stages. The first stage is the measurement model and the second stage is the structural model. 


\section{Findings and Analysis}

\subsection{Profile of Respondents}

Below table shows the profile of respondents. The result found that $75.24 \%$ respondents were female and $24.76 \%$ of respondents were male. In addition, most of the respondents are aged between $31-50(68.1 \%)$, majority of respondents are educated to undergraduate $(44.76 \%)$ and post graduate $(28.57 \%)$. Mostly living in Jakarta $(53.81 \%)$ with quite a variety of professions.

Table 1. Profile of Respondents

\begin{tabular}{lccc}
\hline & Characteristics & Frequency (pax) & Percentage \\
\hline Gender: & Male & 52 & $24.76 \%$ \\
& Female & 158 & $75.24 \%$ \\
Usia: & & $\mathbf{2 1 0}$ & $\mathbf{1 0 0 . 0 0 \%}$ \\
& $31-40$ & 48 & $22.86 \%$ \\
& $41-50$ & 98 & $46.67 \%$ \\
& $>50$ & 45 & $21.43 \%$ \\
Domicile: & & 19 & $9.05 \%$ \\
& Jakarta & $\mathbf{2 1 0}$ & $\mathbf{1 0 0 . 0 0 \%}$ \\
Education: & Bodetabek & 113 & $53.81 \%$ \\
& & 97 & $46.19 \%$ \\
& High School & $\mathbf{2 1 0}$ & $\mathbf{1 0 0 . 0 0 \%}$ \\
& Diploma & 20 & $9.52 \%$ \\
& Undergraduate & 36 & $17.14 \%$ \\
& Post Graduate \&Doctoral Degree & 94 & $44.76 \%$ \\
Occupation: & & 60 & $28.57 \%$ \\
& Office workers & $\mathbf{2 1 0}$ & $\mathbf{1 0 0 . 0 0 \%}$ \\
& Entrepreneur & 60 & $28.57 \%$ \\
& Teacher \& Lecturer & 44 & $20.95 \%$ \\
& Housewife & 40 & $19.05 \%$ \\
& & 21 & $10.00 \%$ \\
\hline
\end{tabular}

\subsection{Reliability Test}

For assessing the internal consistency (reliability) of data, Cronbach's alpha and Composite reliability values are used. The data are reliable if the constructs have Cronbach alpha values equal or more than 0.70 ) and the composite reliability values of the constructs are greater than 0.70 [19]. The table 2 below shows that all the constructs have Cronbach alpha and composite reliability values of more than 0.70 that ensures good internal consistency or reliability of data [19].

Table 2. Measurement Properties of Constructs

\begin{tabular}{cccc}
\hline Variable & Composite Reliability & Cronbach's Alpha & Result \\
\hline ISLAM & 0.836 & 0.755 & Reliable \\
IMAN & 0.911 & 0.853 & Reliable \\
IHSAN & 0.878 & 0.827 & Reliable \\
Moslem Religiosity & 0.899 & 0.831 & Reliable \\
Eco-Literacy & 0.874 & 0.805 & Reliable \\
Environmental Concern & 0.826 & 0.685 & Reliable \\
Environmental Behavior & 0.876 & 0.830 & Reliable \\
\hline
\end{tabular}




\subsection{Convergent Validity}

To evaluate convergent validity, this study considers the Loadings Indicator and Average Variance Extracted (AVE). The general rule is that the Indicator Loadings standard must be 0.7 or higher, and the Indicator Loadings of all indicators must be statistically significant. For AVE value criteria, at least $0.50>$ higher. The AVE value above 0.50 indicates that, on average, the construct explains more than half of the indicator variance. Conversely, if the AVE value is less than 0.50 it indicates that, on average, more variance remains in the item error than in the variance described by the construct.

Table 3. Convergent Validity Test Results

\begin{tabular}{lccccc}
\hline Variable & Indicator & Loading Factor & AVE & p-value & Results \\
\hline ISLAM & ISL1 & 0.710 & & $<0.001$ & Valid \\
& ISL2 & 0.692 & & $<0.001$ & Valid \\
& ISL3 & 0.658 & 0.506 & $<0.001$ & Valid \\
& ISL4 & 0.773 & & $<0.001$ & Valid \\
& ISL5 & 0.719 & & $<0.001$ & Valid \\
IMAN & IMAN1 & 0.892 & & $<0.001$ & Valid \\
& IMAN2 & 0.896 & 0.773 & $<0.001$ & Valid \\
IHSAN & IMAN3 & 0.849 & & $<0.001$ & Valid \\
& IHSAN1 & 0.752 & & $<0.001$ & Valid \\
& IHSAN2 & 0.757 & & $<0.001$ & Valid \\
& IHSAN3 & 0.743 & 0.591 & $<0.001$ & Valid \\
& IHSAN4 & 0.775 & & $<0.001$ & Valid \\
RELIGIOSITAS & IHSAN5 & 0.817 & & $<0.001$ & Valid \\
& RELIGI1 & 0.895 & & $<0.001$ & Valid \\
& RELIGI2 & 0.808 & 0.748 & $<0.001$ & Valid \\
LITERACY & RELIGI3 & 0.889 & & $<0.001$ & Valid \\
& LITER1 & 0.856 & & $<0.001$ & Valid \\
& LITER2 & 0.786 & 0.635 & $<0.001$ & Valid \\
& LITER3 & 0.850 & & $<0.001$ & Valid \\
& LITER4 & 0.683 & & $<0.001$ & Valid \\
CONCERN & CONCERN1 & 0.780 & & $<0.001$ & Valid \\
& CONCERN2 & 0.785 & 0.613 & $<0.001$ & Valid \\
& CONCERN3 & 0.784 & & $<0.001$ & Valid \\
BEHAVIOR & BEHAVE1 & 0.664 & & $<0.001$ & Valid \\
& BEHAVE1 & 0.718 & & $<0.001$ & Valid \\
& BEHAVE1 & 0.775 & 0.542 & $<0.001$ & Valid \\
& BEHAVE1 & 0.792 & & $<0.001$ & Valid \\
& BEHAVE1 & 0.745 & & $<0.001$ & Valid \\
& BEHAVE1 & 0.717 & & $<0.001$ & Valid \\
\hline
\end{tabular}

From Table 4 it can be seen that the Avarage Variance Extracted (AVE) value of each variable is in accordance with the conditions above 0.50 indicating that the instrument for each variable is valid. And for the value of the loading indicator, although there are still indicator values $<0.70$, however, for exploratory research, several indicators with a loading factor between $0.6-0.7$ can be considered to be maintained with a significant $p$ value $(p<0.05)$ [20] 


\subsection{Discriminant Validity}

Discriminant validity is tested to see whether two variables are different or not. Discriminnat validity is established when the items loadings on their measured construct are all larger than cross-loadings on other constructs and the square root of each construct's average variance extracted (AVE) is higher than its correlations with other constructs. It is clear from Table 2 that all the items are well loaded on their constructs and much upper than the cross loadings on other constructs which indicates the discriminant validity of the measurement model

Table 4. Loading Factors dan Cross Loading

\begin{tabular}{lccccccc}
\hline & ISLAM & IMAN & IHSAN & RELIGIOSITY & LITERACY & CONCERN & BEHAVE \\
\hline ISL1 & $\mathbf{0 . 7 1 0}$ & -0.164 & -0.023 & 0.019 & -0.013 & -0.031 & -0.012 \\
ISL2 & $\mathbf{0 . 6 9 2}$ & -0.234 & 0.207 & 0.069 & -0.144 & -0.104 & 0.000 \\
ISL3 & $\mathbf{0 . 6 5 8}$ & 0.169 & -0.373 & 0.434 & -0.138 & 0.030 & 0.188 \\
ISL4 & $\mathbf{0 . 7 7 3}$ & 0.071 & 0.118 & -0.258 & 0.101 & 0.007 & -0.070 \\
ISL5 & $\mathbf{0 . 7 1 9}$ & 0.157 & 0.039 & -0.205 & 0.169 & 0.095 & -0.084 \\
IMAN1 & 0.104 & $\mathbf{0 . 8 9 2}$ & -0.072 & 0.074 & 0.057 & -0.059 & -0.005 \\
IMAN2 & -0.072 & $\mathbf{0 . 8 9 6}$ & 0.004 & 0.115 & -0.039 & 0.017 & 0.009 \\
IMAN3 & -0.034 & $\mathbf{0 . 8 4 9}$ & 0.071 & -0.199 & -0.018 & 0.044 & -0.004 \\
IHSAN1 & -0.019 & $\mathbf{- 0 . 0 2 9}$ & $\mathbf{0 . 7 5 2}$ & -0.059 & 0.042 & 0.101 & 0.032 \\
IHSAN2 & -0.046 & 0.218 & $\mathbf{0 . 7 5 7}$ & 0.140 & 0.035 & -0.138 & 0.194 \\
IHSAN3 & 0.100 & -0.364 & $\mathbf{0 . 7 4 3}$ & 0.077 & -0.078 & -0.025 & -0.084 \\
IHSAN4 & 0.006 & 0.079 & $\mathbf{0 . 7 7 5}$ & -0.092 & 0.009 & 0.067 & -0.098 \\
IHSAN5 & -0.037 & 0.081 & $\mathbf{0 . 8 1 7}$ & -0.059 & -0.009 & -0.006 & -0.040 \\
RELIGI1 & 0.045 & -0.008 & 0.055 & $\mathbf{0 . 8 9 5}$ & -0.094 & 0.025 & -0.017 \\
RELIGI2 & 0.011 & -0.152 & -0.088 & $\mathbf{0 . 8 0 8}$ & 0.163 & -0.088 & 0.026 \\
RELIGI3 & -0.056 & 0.146 & 0.025 & $\mathbf{0 . 8 8 9}$ & -0.053 & 0.055 & -0.007 \\
LITER1 & -0.047 & 0.093 & -0.062 & -0.043 & $\mathbf{0 . 8 5 6}$ & 0.059 & 0.043 \\
LITER2 & 0.083 & -0.201 & 0.004 & 0.029 & $\mathbf{0 . 7 8 6}$ & -0.074 & -0.122 \\
LITER3 & 0.100 & -0.155 & 0.038 & 0.009 & $\mathbf{0 . 8 5 0}$ & -0.175 & 0.044 \\
LITER4 & -0.160 & 0.308 & 0.025 & 0.010 & $\mathbf{0 . 6 8 3}$ & 0.229 & 0.032 \\
CONCERN1 & 0.103 & -0.087 & -0.025 & 0.030 & 0.019 & $\mathbf{0 . 7 8 0}$ & -0.182 \\
CONCERN2 & -0.097 & -0.020 & -0.021 & 0.060 & 0.076 & $\mathbf{0 . 7 8 5}$ & 0.065 \\
CONCERN3 & -0.006 & 0.107 & 0.046 & -0.089 & -0.095 & $\mathbf{0 . 7 8 4}$ & 0.116 \\
BEHAVE1 & -0.043 & 0.163 & -0.073 & -0.191 & 0.158 & -0.015 & $\mathbf{0 . 6 6 4}$ \\
BEHAVE2 & 0.081 & -0.187 & 0.064 & 0.047 & -0.093 & 0.178 & $\mathbf{0 . 7 1 8}$ \\
BEHAVE3 & -0.022 & -0.185 & 0.190 & 0.160 & 0.000 & -0.086 & $\mathbf{0 . 7 7 5}$ \\
BEHAVE4 & 0.102 & -0.213 & 0.062 & 0.026 & 0.094 & -0.079 & $\mathbf{0 . 7 9 2}$ \\
BEHAVE5 & -0.015 & 0.078 & -0.182 & 0.020 & 0.028 & 0.026 & $\mathbf{0 . 7 4 5}$ \\
BEHAVE6 & -0.116 & 0.391 & -0.081 & -0.094 & -0.185 & -0.010 & $\mathbf{0 . 7 1 7}$ \\
\hline
\end{tabular}

Secondly, Table 5 below demonstrates that the square root of the AVEs is higher than the orrelation between that construct and the other constructs which satisfy another criterion of discriminant validity of the variables of this study. 
Table 5. Discriminant Validity Test Results

\begin{tabular}{lccccccc}
\hline & ISLAM & IMAN & \multicolumn{1}{c}{ IHSAN RELIGIOSITY LITERACY } & CONCERN BEHAVE \\
\hline ISLAM & $\mathbf{( 0 . 7 1 1 )}$ & & & & & & \\
IMAN & 0.629 & $\mathbf{( 0 . 8 7 9 )}$ & & & & & \\
IHSAN & 0.432 & 0.621 & $\mathbf{( 0 . 7 6 9 )}$ & & & & \\
RELIGIOSITY & 0.463 & 0.607 & 0.483 & $\mathbf{( 0 . 8 6 5 )}$ & & & \\
LITERACY & 0.109 & 0.315 & 0.442 & 0.271 & $\mathbf{( 0 . 7 9 7 )}$ & & \\
CONCERN & 0.232 & 0.284 & 0.462 & 0.319 & 0.460 & $\mathbf{( 0 . 7 8 3 )}$ & \\
BEHAVE & 0.101 & 0.271 & 0.496 & 0.332 & 0.515 & 0.504 & $\mathbf{( 0 . 7 3 7 )}$ \\
\hline
\end{tabular}

\subsection{Goodnes of Fit (GoF)}

The results of the goodness of fit estimation from the research model processed with the WarpPLS Version 7.0 2020 application have several indicators of the Goodnes of Fit (GoF) model and quality indexes that meet the requirements include:

Table 6. Goodnes of Fit (GoF)

\begin{tabular}{ccccc}
\hline No & Goodness offit index & Cut-off value & Output & Result \\
\hline 1. & APC & $\mathrm{p}<0,05$ & $0,285, \mathrm{P}<0,001$ & Good Fit \\
2. & ARS & $\mathrm{p}<0,05$ & $0,309, \mathrm{P}<0,001$ Good Fit \\
3. & AARS & $\mathrm{p}<0,05$ & $0,302, \mathrm{P}<0,001$ Good Fit \\
4. & AVIF & Acceptable if $<=5$, ideally $<=3.3$ & 1,572 & Accepted \\
5. & AFVIF & Acceptable if $<=5$, ideally $<=3.3$ & 1,872 & Ideal \\
6. & GOF & small $\geq 0,1 ;$ medium $\geq 0,25 ;$ large $\geq 0,36$ & 0,441 & Large \\
7. & SPR & Acceptable if 0.7, ideally $=1$ & 1,000 & Ideal \\
8. & RSCR & Acceptable if 0.9, ideally $=1$ & 1,000 & Ideal \\
9. & SSR & Acceptable if 0.7 & 1,000 & Accepted \\
10. & NLBCDR & Acceptable if 0.7 & 1,000 & Accepted \\
\hline
\end{tabular}

\subsection{Hypotheses Testing}

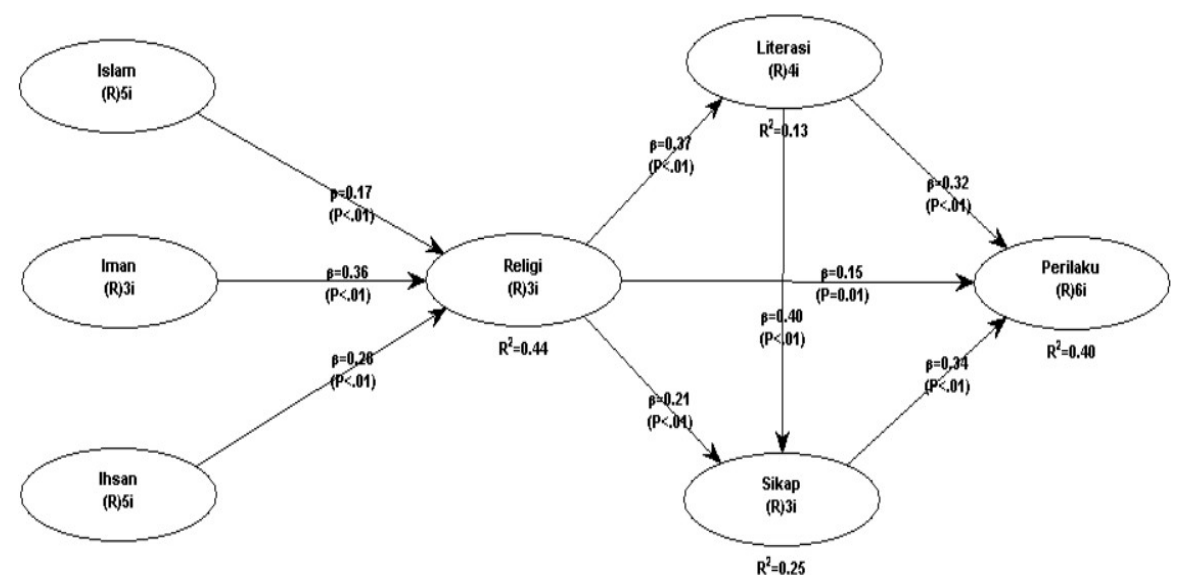

Fig. 2. SEM Output 
As the realibility and validity were established in the measurement, the structural model ouput was used for testing the hypothesis in this study. The ouputs are presented in Table 7.

\begin{tabular}{|c|c|c|c|c|c|c|}
\hline & Hyphotesized Path & $\begin{array}{c}\text { Standardized } \\
\text { Path Coefficient }\end{array}$ & $\begin{array}{c}\text { Effect } \\
\text { Size }\end{array}$ & p-Value & $\begin{array}{c}\text { Significant } \\
\text { Level }\end{array}$ & Results \\
\hline $\mathrm{H} 1$ & ISLAM RELIGI & 0,171 & 0,090 & 0,006 & $*$ & Supported \\
\hline $\mathrm{H} 2$ & IMAN RELIGI & 0.356 & 0.222 & $<0.001$ & $* * *$ & Supported \\
\hline $\mathrm{H} 3$ & IHSAN RELIGI & 0.260 & 0.133 & $<0.001$ & $* * *$ & Supported \\
\hline $\mathrm{H} 4$ & RELIGI LITERACY & 0.366 & 0.134 & $<0.001$ & $* * *$ & Supported \\
\hline H5 & RELIGI CONCERN & 0.209 & 0.070 & $<0.001$ & $* * *$ & Supported \\
\hline H6 & RELIGI BEHAVIOR & 0.148 & 0.056 & 0.014 & $* *$ & Supported \\
\hline $\mathrm{H} 7$ & $\begin{array}{l}\text { LITERACY } \\
\text { BEHAVIOR }\end{array}$ & 0.323 & 0.169 & $<0.001$ & $* * *$ & Supported \\
\hline $\mathrm{H} 8$ & $\begin{array}{l}\text { CONCERN } \\
\text { BEHAVIOR }\end{array}$ & 0.338 & 0.177 & $<0.001$ & $* * *$ & Supported \\
\hline
\end{tabular}

The finding support Hypotheis (1) one, as the path coefficient value is ( $=0.171)$, and the effect size score is 0.090 (significant at $\mathrm{p}=0.006$ ) which confirms the positive effect of Islamic level (ISLAM) on Moslem religiosity (RELOGIOSITY). This means that religious practices through obligatory rituals such as praying, paying zakat, fasting, hajj, and other sunnah worship can affect the level of religiosity but the size of the effect is still weak to medium.

Hypothesis (2) two also supported the path coefficient value is $(=0.356)$, with a significance value $(p<0.001)$ and an effect size score of 0.222 . This condition reflects that the level of faith (IMAN) is able to encourage the level of religiosity of a Moslem (RELIGIOSITY) in a positive and significant way with a medium to large impact. The level of faith of a Moslem involves understanding and believing in Allah Subhanahu Wa Ta'ala, the prophets, angels, the holy book the Qur'an, and belief in 'akhira'. The belief in these six things encourages a Moslem to be more religious.

Spirit of Ihsan (IHSAN) has a significant and positive effect on Moslem religiosity (RELIGIOSITY), with coefficient value of $(=0.260)$, significant at $p<0.001$, and the effect size score of 0.133 , hence Hypothesis (3) three is supported. This means that the spirit to do good as a form of the inner dimension of a Moslem related to the understanding, belief and devotion to Allah Subhanahu Wa Ta'ala, is sufficient to have a role in shaping the level of religiosity of a Moslem.

The testing for hypothesis (4) four, is to prove the influence of level of Moslem religiosity (RELIGIOSITY) on eco-literacy (LITERATION) which results in a path coefficient score of $(=0.366)$ with a significance value of $\mathrm{p}<0.001$, which means that the influence of Moslem religiosity on environmental literacy is positive and significant, effect size weak to medium with score of 0.134 . These results support the hypothesis which states that: "The level of Moslem religiosity has a positive and significant effect on environmental literacy", and it can be stated that there is a direct influence between the two. This means that the higher the level of religiosity of a Moslem, he will continue to try to learn about the relationship between humans and nature, because a Moslem with a high level of religiosity will try to practice religion by kaffah (overall). This also illustrates that the religious aspect related to environmental education is very important to encourage environmental protection practices among Muslims. This situation is the embodiment of a Muslim as caliph on earth as stated in the Qur'an QS 2:30 [12]. 
The testing for hypothesis (5) five, is to test the effect of level of Moslem religiosity (RELIGIOSITY) on caring attitudes towards environmental sustainability (CONCERN) which results in a path coefficient score of $(=0.209)$ with a significance value of $p<0.001$, meaningthat there is a positive and significant influence between a person's level of religiosityof Moslemtowards the attitude of caring for environmental sustainability with an influence size weak to medium, the effect size score is 0.070 . These results support the hypothesis which states that: "The level of Moslem religiosity has a positive and significant direct effect on Caring Attitudes on Environmental Sustainability", and it can be stated that there is a direct influence between the two. This means that the higher the level of religiosity of a Moslem, the higher his concern for environmental sustainability. This condition reflects that there is a degree of awareness of individual Moslem towards environmental problems and their readiness to participate in mitigating these problems. Thus, it is evident that individual sensitivity to environmental problems and individual willingness to be part of the solution to environmental conservation is also influenced by awareness as a reflection of the level of religiosity. A high level of religiosityand reflected in an attitude of caring for the environment, for a Muslim is an effort to fulfill thecall of Allah in Surah Al Anbiya verse 107.

The testing for hypothesis (6) sixth, is related to proving the direct effect of the level of Moslem religiosity (RELIGIOSITY) on environmentally friendly behavior (BEHAVIOR), which resulted in the path coefficient value of $(=0.148)$ with a significance value of 0.014 $(p<0.05)$, and a score of effect size of 0.056 . This result means that the influence of Moslem religiosity on environmentally friendly behavior is positive and significant, with the effect size weak to medium effect group. These results also support the hypothesis which states: "The level of Moslem religiosity has a positive and significant direct effect on Environmentally Friendly Behavior", and it can be stated that there is a direct influence between the two, but the size of the influence is weak. This needs to be mediated by other factors so that the influence of the level of religiosity on friendly behavior environment becomes more bigger.

The testing for hypothesis (7) seven is to test the direct effect of eco-literacy (LITERATION) on environmentally friendly behavior (BEHAVIOR). The value of the path coefficient obtained is $(=0.323)$. This shows that the relationship between environmental literacy and environmentally friendly behavior is positive. The higher the level of eco-literacy will increase environmentally friendly behavior. Testing the relationship between the two variables shows a significant value $(\mathrm{p}<0.001)$, so the hypothesis which states that: "EcoLiteracy has a positive and significant effect on Environmentally Friendly Behavior", is supported and can be stated that there is a direct influence between environmental literacy on environmentally friendly attitudes. The effect size score obtained is 0.169 , indicating that the effect is classified as medium to large. This result means that the higher the individual's understanding of environmental issues, such as: the impact of global warming, the impact of acid rain, ozone depletion, and the dangers of plastic bags, the more motivated they will be to behave in an environmentally friendly manner. These results in line with the result of research condected by (Hassan, 2014; Ismoyo et.al., 2020) [8], [13], which proves that an understanding of how and not to damage the environment can increase attention to the environment and care for the environment. including in this case consumers to buy or pay more for environmentally friendly products. In the context of Islamic ecology, environmental literacy raises awareness that humans are to preserve the environment, as Allah says in the Qur'an QS 17:36 and QS 21:7.

The testing for hypothesis (8) eight is to test the direct effect of caring attitude on environmental sustainability (CONCERN) on environmentally friendly behavior (BEHAVIOR). Testing the relationship between these two variables resulted in a path 
coefficient score of $(=0.338)$ with a significance value of $\mathrm{p}<0.001$, meaning the influence of caring attitudes towards environmental sustainability on environmentally friendly behavior is positive and significant, and belongs to the medium-large effect size group with an effect scoresize 0.177 . These results support the hypothesis which states: "Care for Environmental Sustainability has a positive and significant effect on Environmentally Friendly Behavior", and can be stated if there is a direct influence between caring attitudes towards environmental sustainability and environmentally friendly behavior. This result means that the higher the attitude of caring for the environment will increase the environmentally friendly behavior significantly. Someone who has a high concern for environmental sustainability will be willingto make special efforts to protect the environment such as sorting "organic" and "nonorganic" waste, and tends to choose environmentally friendly products over nonenvironmentally friendly products if the product quality is the same. This spirit of preserving nature is a real stepin implementing Surah Al Araf verse 56.

\subsection{Mediation Analysis}

Table 8. Mediation Effect

\begin{tabular}{|c|c|c|c|c|c|c|c|c|c|c|}
\hline & & yphotesized Path & & & $\begin{array}{l}\text { Direct } \\
\text { Effect }\end{array}$ & $\begin{array}{r}\text { Indirect } \\
\text { Effect }\end{array}$ & $\begin{array}{r}\text { Total } \\
\text { Effect }\end{array}$ & p- Value & VAF & Result \\
\hline H9 & $\begin{array}{l}\text { RELIGI } \\
\text { BEHAVIOR }\end{array}$ & LITERACY & -- & $>$ & 0.148 & 0,118 & 0,266 & $<0.001$ & $44.4 \%$ & $\begin{array}{c}\text { Partial } \\
\text { mediation }\end{array}$ \\
\hline $\mathrm{H} 10$ & $\begin{array}{l}\text { RELIGI } \\
\text { BEHAVIOR }\end{array}$ & CONCERN & -- & $>$ & 0.148 & 0,071 & 0,266 & $<0.001$ & $32.3 \%$ & $\begin{array}{c}\text { Partial } \\
\text { mediation }\end{array}$ \\
\hline H11 & $\begin{array}{l}\text { LITEARCY } \\
\text { BEHAVIOR }\end{array}$ & CONCERN & -- & $>$ & 0.323 & 0,135 & 0,458 & $<0.001$ & $29,4 \%$ & $\begin{array}{l}\text { Partial } \\
\text { mediation }\end{array}$ \\
\hline $\mathrm{H} 12$ & $\begin{array}{l}\text { RELIGI L } \\
-->\text { BEHAV }\end{array}$ & $\begin{array}{l}\text { ITEARCY CON } \\
\text { IOR }\end{array}$ & CERN & & 0.148 & 0,238 & 0,386 & $<0.005$ & $30,6 \%$ & $\begin{array}{c}\text { Partial } \\
\text { mediation }\end{array}$ \\
\hline
\end{tabular}

\section{Result and Discussion}

The major objective of the research is to provide a causal model of religios factors, ecoliteracy and attitudes on environmentally friendly behavior. The results obtained from hypothesis testing show that all exogenous variables (religiosity, eco-literacy and environmental concern) have a significant direct effect on environmentally friendly behavior; and the ecoliteracy variable among them has the greatest effect on environmentally friendly behavior. While the most encouraging factor for a Muslim's religiosity is the faith factor.

The findings in this research show that Moslem religiosity has positif and significant impact to eco-literacy, envirinmental concern and on environmentally friendly behavior with a weak to medium level of influence. This findings indicates the need to mediate other factors so that the influence of the level of religiosity on environmentally friendly behavior becomes greater. From the results of hypothesis testing, it is evident that the variables of eco-literacy and environmental concern can act as a partial mediation. This proof means that the influence of religiosity on environmentally friendly behavior cannot happen directly by itself. However, each individual needs to gain understanding and have a caring attitude towards environmental sustainability first so that it can be realized into environmentally friendly behavior. In the context of Islamic ecology, environmental literacy raises awareness that humans are required to preserve the environment.

These findings also indicate the influence of religiosity on environmentally friendly behavior through eco-literacy mediation, begin with the formation of a individuals's 
understanding and belief in the religious values that he adheres to and carries out as a result of the influence of the level of Islam, faith and Ihsan's attitude. These three dimensions provide enlightenment to individual Moslem to continue to learn to increase their knowledge (knowledge induced), so that their literacy level increases and ultimately encourages them to behave in an environmentally friendly manner based on and considering Islamic moral values.

Understanding of the environment and all its problems is a knowledge base that will helpa person to develop his understanding that natural resources will be destroyed if not preserved [8]. The concern of a Individuals regarding the potential for environmental damage and their willingness to take preventive action, fosters an attitude of caring for environmental sustainability that has been formed previously from the influence of religiosity. Thus, the increasing knowledge of individuals through ecological understanding will be mediated by an attitude of caring for the environment, so that environmentally friendly behavior is realized.

\section{Implications and Coclusions}

This research is an initial attempt to establish the relationship between moslem religiosity

comprehensively and ecologically conscious behaviour and generate a new research area of green behaviour based on religious spirit. This research produces findings that are useful for the community, employees, company leaders, and policy makers in the public sector to improve the growth of awareness and concern for the preservation of the natural environment. Society can discuss religious aspects with the topic of the relationship between God, human and nature as part of a campaign for environmental sustainability. Instead of environment protection propaganda and education, society should lay the key point of religiosity to foster an ecologically conscious behaviour.

\section{Scope for Future Research}

Future research is expected to be able to complement the research by adding predictors in the field of public policy with a wider sample area coverage.

\section{Acknowledgments}

We want to show our gratitude to Facukty of Econimics and Business University of Trisakty that have provided support, insight and expertise that are very helpfulin research.

\section{References}

[1] I. Abdul-Matin, Green Deen: What Islam teaches about protecting the planet, 1st ed. San Francisco: Berrett-Koehler Publishers, 2010.

[2] A. Bagheri and K. Alali, Islamic Bioethics: Current Issues and Challenges. London: World Scientific Publishing Europe Ltd, 2018.

[3] M. N. Khan and M. D. Kirmani, "Role of religiosity in purchase of green products by Muslim students: Empirical evidences from India," J. Islam. Mark., 2018.

[4] N. D. M. Mahudin, N. M. Noor, M. A. Dzulkifli, and N. S. Janon, "Religiosity among Muslims: A scale development and validation study," Makara Hum. Behav. Stud. Asia, vol. 20, no. 2, pp. 109-120, 2016.

[5] A. Davari, P. Iyer, and D. Strutton, "Investigating moral links between religiosity, 
altruism, and green consumption,” J. Nonprofit Public Sect. Mark., vol. 29, no. 4, pp. 385-414, 2017.

[6] S. Wang, J. Wang, J. Li, and K. Zhou, "How and when does religiosity contribute to tourists' intention to behave pro-environmentally in hotels?," J. Sustain. Tour., vol. 28, no. 8, pp. 1120-1137, 2020.

[7] E. Rafsanjani and N. Asnawi, "Religiosity and environmentally friendly behavior of millennial muslim consumers," Manag. Econ. J., vol. 4, no. 2, pp. 143-152, 2020.

[8] M. Ismoyo, D. Suhartanto, and N. Hardiyanto, "Apakah Religiusitas Mempengaruhi Sikap Muslim Gen Z terhadap Produk Ramah Lingkungan?," in The 11th Indusstrial Research Workshop and National Seminar, 2020, pp. 1173-1179.

[9] P. Jadmiko, "Peran Penilaian Etis pada Pengaruh Religiusitas terhadap Perilaku Pembelian Ramah Lingkungan,” J. Manaj. Univ. Bung Hatta, vol. 13, no. 2, pp. 25-30, 2018.

[10] R. Fitri, D. Ariesandi, and P. Jadmiko, "Religiusitas dan Persepsi Pengetahuan Lingkungan terhadap Pembelian Produk Ramah Lingkungan," Manaj. dan Kewirausahaan, vol. 10, no. 4, pp. 1-8, 2019.

[11] T. Islam and U. Chandrasekaran, "Religiosity and ecologically conscious consumption behaviour," Asian J. Bus. Res. ISSN, vol. 5, no. 2, pp. 18-30, 2016.

[12] Departemen Agama RI, Al-Qur'an Tajwid dan Terjemahannya. Bnadung: PT Syaamil Cipta Media, 2006.

[13] S. Hasnah Hassan, "The role of Islamic values on green purchase intention," J. Islam. Mark., vol. 5, no. 3, pp. 379-395, Jan. 2014, doi: 10.1108/JIMA-11-2013-0080.

[14] R. Gifford and R. Sussman, Environmental attitudes. In 'The Oxford Handbook of Environmental and Conservation Psychology. Oxford: Oxford University Press, 2012.

[15] S. M. Cruz and B. Manata, "Measurement of environmental concern: A review and analysis," Front. Psychol., vol. 11, p. 363, 2020.

[16] S. Mokhlis, "Religious Contrast in Costumer Shopping Style; an analytic Factor Comparison," J. Bus. Stud. Q., vol. 2, 2006.

[17] M. H. Seif and S. Nematolahi, "The Effective Factors on Environmentally Friendly Behavior: A Case Study," Libr Philos Pr., vol. September, 2019.

[18] J. F. Hair, R. E. Anderson, R. L. Tatham, and W. C. Black, Multivariate Data Analysis, 6th ed. New Jersey: Prentice Hall, 2010.

[19] S. Mokhlis, "The Effect of Religiosity on Shopping Behavior: An Exploratory Study During the Transitional Period in China," J Am Acad Bus, vol. 9, no. 1, pp. 64-74, 2006.

[20] J. F. Hair, G. T. M. Hult, C. Ringle, and S. M. A, primer on partial least squares structural equation modeling (PLS-SEM). London: Sage Publications, 2014. 